\title{
Major Events in Gogol's Life
}

1809 Mar. 20: Born in Bolshie Sorochintsy, Poltava Province, Mirgorod District, Ukraine.

I82I Enters Gimnaziya at Nezhin.

I825 Death of father.

I828 Finishes Gimnaziya.

Dec.: Leaves for St: Petersburg.

I829 Publishes Hanz Kuechelgarten, an "idyll in verse," under the pseudonym "V. Alov."

Aug.-Sept.: First trip to Europe (Germany). On returning, he unsuccessfully attempts to become a professional actor.

Nov.: Enters civil service as a minor official.

I830 Begins publishing prose fiction ("Bisavryuk, or St. John's Eve," and one chapter of The Hetman, an unfinished historical novel).

I83I Becomes a history teacher in the Patriotic Institute. May 20: Meets Pushkin for the first time. Sept.: Publishes Evenings on a Farm Near Dikanka, Part I.

I832 Publishes Evenings on a Farm Near Dikanka, Part 2. I833 Works on various articles and stories. 
I834 Appointed adjunct professor of world history, St. Petersburg University.

1835 Jan.: Publishes Arabesques. Mar.: Publishes Mirgorod.

Dec.: Dismissed from teaching position.

I836 Apr. 19: Premiere of The Inspector General, St. Petersburg.

June 6: Goes abroad, travels through Western Europe the rest of the year.

I837 Jan. 29: Death of Pushkin.

Mar. 26: Arrives in Rome.

I838-4I Lives in Rome, travels in Europe, makes two trips to Russia.

I842 In Russia. Prepares edition of collected works; publishes first two volumes.

May: Publishes Dead Souls, Part $\mathbf{I}$.

June: Returns to Europe.

Dec. 9: Premiere of Marriage, St. Petersburg.

I843 In Europe.

Jan.: Publishes third and fourth volumes of collected works.

Feb.: Premiere of Marriage and The Gamblers in

Moscow.

I844-46 In Europe. Works on Dead Souls, Part 2.

June-July I 845 : Burns manuscript.

I847 In Europe.

Jan.: Publishes Selected Passages from Correspondence with Friends.

June-July: Works on apologia (posthumously published as "An Author's Confession").

I848 In Europe.

Mid-Feb.: Travels to Holy Land.

Apr. II: Returns to Russia, there to remain.

I849-5I In Russia; works on Dead Souls, Part 2.

1852 In Russia.

Feb. II-I 2: Burns manuscript of Dead Souls, Part 2.

Feb. 2I: Dies.

Feb. 25 : Buried. 